CERIF: S115

\author{
Milos Zdravković*, LLM
}

\title{
THEORETICAL DISAGREEMENT ABOUT LAW
}

As the dominant direction of the study of legal phenomena, legal positivism has suffered criticisms above all from representatives of natural law. Nevertheless, the most complex criticism of legal positivism came from Ronald Dworkin. With the methodological criticism he formed in "Law's Empire", Dworkin attacked the sole foundations of legal positivism and his main methodological assumptions. Quoting the first postulate of positivism, which understands the law as a fact, Dworkin claims that, if this comprehension is correct, there could be no dispute among jurists concerning the law, except if some of them make an empirical mistake while establishing facts. Since this is not the case, Dworkin proves that this is actually a theoretical disagreement which does not represent a disagreement about the law itself, but about its morality. On these grounds, he rejects the idea of law as a fact and claims that the law is an interpretive notion, which means that disagreements within jurisprudence are most frequently interpretative disagreements over criteria of legality, and not empirical disagreements over historic and social facts.

Key words: Jurisprudence. - Grounds of law. - Dworkin. - Theoretical disagreement. - Criteria of legality.

\section{INTRODUCTION}

Developing his own theory of law, Ronald Dworkin has offered two different criticisms of legal positivism. The first criticism is aimed at the phenomenological deficiencies of positivism. With this type of criticism Dworkin has proven the importance of legal principles, especially in hard cases. By stressing their importance, he has brought into question the explanatory power of legal positivism, which is not capable of properly defining legal practice since it excludes legal principles from its de-

* Lecturer, University of Belgrade Faculty of Law, milos.zdravkovic@ius.bg.ac. $r s$. 
scription. In his second criticism, outlined in his most reputable work "Law's Empire", Dworkin attacks the sole foundations of legal positivism and its main methodological postulates. Quoting the main edification of modern positivism which understands the law as a social fact, Dworkin claims that if this understanding is correct, there could be no disputes among jurists concerning the law, except if one of them made an empirical mistake while establishing facts. Since this is not the case, Dworkin has proven that this is the issue of theoretic disagreement about the law itself. On these foundations, he rejects the idea of law as a fact and states an original presumption on law as an interpretive concept, thus pointing out that disagreements within jurisprudence are most frequently interpretive disagreements over criteria of legality, and not empirical disagreements on historic and social facts.

Dworkin bases his second criticism, which could also be called methodological criticism, on an analysis of hard cases. Even though adjudication is not the only characteristic element of legal practice, it is, according to Dworkin, the most important as the court procedure combines all or most other elements. If one bears in mind the importance of the judiciary and adjudication in the Anglo-Saxon legal system, it should not be surprising that Dworkin, during the development of his methodological criticism, directed his attention in this direction. Court decisions confirm or dispute the rights of individuals or groups, but these decisions are frequently of more general importance. United States Supreme Court decisions can declare invalid legal acts which are not in compliance with the Constitution of the United States. This is the body with the final say in many issues which are of interest for the entire political community. During court procedures painful and controversial topics for the whole community are frequently raised, which have undisputable moral dimensions, like the death penalty, racial segregation, euthanasia, etc. These are, therefore, the reasons which have compelled Dworkin to take adjudication as the focal point around which he further organizes his methodological criticism of legal positivism.

\section{WHAT IS THEORETICAL DISAGREEMENT ABOUT LAW?}

Adjudication, as per rule, initiates three different types of disputable issues: 1) the question of facts, 2) question of law and 3) intertwined issues of political morality and fidelity to the law. ${ }^{1}$ There can be disagreements with any of these three issues. The first issue mainly deals with determining exact facts which have happened in the past and are relevant to the case being deliberated. However, this issue is not of a purely tech1986, 3 .

1 Ronald Dworkin, Law's Empire, Cambridge, MA: Harvard University Press, 
nical character, since it cannot be merely reduced to determining of facts, but also involves determining which facts are relevant to the case, and which are not. The third issue relates to determining whether rules on the basis of which the case should be solved are in accordance with moral principles or not and whether the court must necessarily follow and apply rules which deviate from morality. These two issues are known in the legal theory, while the second question - the issue of law- causes the most dilemmas according to Dworkin. There is frequently no consent between judges and lawyers concerning the law which regulates a particular case. In hard cases, members of the same panel of judges cannot agree on whether a rule should be applied to a particular case and whether an adequate rule exists at all. In order to examine what type of disagreement concerns the issue of law and whether the discussion which such disagreement initiates is different than discussions on historical facts and moral questions, Dworkin introduces two distinctions in his analysis of this problem.

The first difference is between the "propositions of law" and "grounds of law". ${ }^{2}$ Propositions of law are those different statements and claims on the content of law within a particular legal system which can be of a very general nature, i.e. "the law forbids states to deny anyone equal protection within the meaning of the Fourteenth Amendment", or, in opposite, very determined - "the law requires Acme Corporation to compensate John Smith for the injury he suffered in its employ last February". According to Dworkin, propositions of law can be true or false. For example, a provision is true that states "the highest permitted speed on the highway is 120 kilometers per hour", while a provision stating that "driving on the highway is prohibited after sunset" would be false. All propositions of law, more precisely - their accurateness, are evaluated "in virtue of other, more familiar kinds of propositions of law that are (as we might put it) parasitic". These more familiar propositions of law represent the grounds of law. A provision would be, therefore, true in Serbia that speed limit on the highway is $120 \mathrm{~km} / \mathrm{h}$ because a majority of deputies of Serbian Parliament voted for the draft law which contains such provisions, and the President of the Republic proclaimed this law. Since, in this particular case, acts of the lawmaker make a proposition of the law onspeed limit accurate, they therefore represent the grounds of the legal system of the Republic of Serbia.

On the basis of differences between propositions of the law and the grounds of law, Dworkin argues that there are two possible types of disagreements concerning law. The first type of disagreement Dworkin calls "empirical disagreement". Judges and attorneys "might agree about the grounds of law - about when the truth or falsity of other, more familiar propositions, makes a particular proposition of law true or false - but

2 Ibid., 4-5. 
disagree about whether those grounds are in fact satisfied in a particular case". ${ }^{3}$ For example, there could be an agreement on the content of a certain proposition of law because it is contained in the law, but there could also be a disagreement on whether this truly is an effective law, since it is arguable whether the law actually came into force.

The second type of disagreement does not relate to the question of whether grounds of law have in fact been obtained in the case of some particular proposition of the law, but what the grounds of law actually are. ${ }^{4}$ Theoretical disagreement on the law, or on the grounds of law, exists among jurists when they agree on what the law actually defines or what the highest court practice says, but they disagree on what the law is in a particular case. One brief view on U.S. court practice can serve as an illustration for this distinction. For example, after the American Civil War and after the victory of North over South, constitutional changes ensued which prohibited slavery. Federal states which belonged to the Confederation were forced to, among other things, respect a provision contained in the Fourteenth amendment of the Constitution which guarantees that no person be denied the right to equal legal protection. Subsequently, the states of the defeated South conducted racial segregation concerning many public goods, which meant that blacks were not disputed the right to, for example, public transport or education, but they could only ride in the back of the bus or only go to schools for blacks. Even though the question of the constitutionality of racial segregation was raised several times before the Supreme Court, only in the case of Brown v. Board of Education from 1954 was it proclaimed unconstitutional. ${ }^{5}$ This case, as well as many others, shows that theoretical disagreements about law exist regardless of agreement concerning the content of legal propositions of law. Even before 1954 and the Brown case, it was very well known what provisions of the Constitution of the United States say and what the practice of the Supreme Court was in this regard, but only in this case did judges decide to declare segregation unconstitutional. This proves that there was no empirical disagreement concerning the content or applicability of provisions of the law, but that there was a theoretical disagreement what the law actually is in the said case, as well as in previous similar cases of racial segregation. According to Dworkin, this and countless other cases support the view that there is frequently no consent on what the grounds of the law are, and whether they can be reduced only to existing laws and court precedents.

\footnotetext{
3 Ibid.

4 See Scott Shapiro, Hart-Dworkin debate, Public Law and Legal Theory Working Paper Series, No. 77, 2007, 29.

5 See Ronald Dworkin, A Matter of Principle, Harvard University Press, Cambridge-Massachusetts, 1985, 295.
} 
Hence, if there is no agreement concerning the identity of the grounds of law, then it cannot be stated for certain for propositions of law whether they are true or false, which means that before stating a claim on truthfulness of the proposition of law a question must be answered on precise criteria for identification of the grounds of law. ${ }^{6}$ Without an answer to that question, discussion concerning the truthfulness of propositions of law cannot be grounded and represents a redirection of attention from the main problem.

\section{NOTION OF LAW AS A PLAIN FACT}

On the basis of his stated observations, Dworkin says that it is stunning that within a modern jurisprudence there is no acceptable theory on disagreement about law. The reason for such a condition in the jurisprudence Dworkin recognizes in the prevailing notion on plain-fact view of law. He describes this notion in the following way: "The law is only a matter of what legal institutions, like legislatures and city councils and courts, have decided in the past. If some body of that sort has decided that workman can recover compensation for injuries by fellow workmen, then that is the law. If it has decided the other way, then that is the law. So questions of law can always be answered by looking in the books where the records of institutional decisions are kept". ${ }^{7}$

According to Dworkin, the notion of plain-fact view of law is comprised of two main elements. First, the grounds of law in each political community are fixed by consensus among legal officials or, more precisely, "if officials agree that facts of type $f$ are grounds of law in their system, then facts of type $f$ are grounds of law in their system". ${ }^{8}$ The second element purports that grounds of law may cover only plain historical facts. This means that law exists exclusively as a plain fact and that the reply to the question of what the law is does not depend in any way on the notion of what the law should actually be. However, by accepting the notion of law as the plain fact, positivism as a dominant theory cannot offer an acceptable response to why courts in a particular moment, as in the Brown case, apply the same rules radically differently and how decisions adopted on the basis of the same legal rule can be so different.

Dworkin argues that positivism is not capable of providing adequate answers to these and many other questions because it starts from the notion of law as a plain fact, meaing that the law is a historical fact

6 S. Shapiro, ibid., 30.

7 R. Dworkin, Law's Empire, 7.

8 S. Shapiro, ibid. 
which never depends on morality. By accepting this notion, one rejects the possibility of theoretical disagreement on law, as according to the first element, the grounds of law are accepted by consensus among officials, so there can be no disagreement in this regard. The only sensible disagreement on law can be in regards to the existence or the lack of existence of plain historical facts, which are actually pure empirical disagreements. In order to dispute the notion of the law as a plain fact Dworkin concentrates on analysis of known hard cases.

One such case comes from British court practice and pertains to the application of the precedent and rules established in previous court deci-

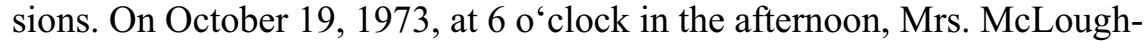
lin received news at home that members of her family were in a terrible traffic accident. She immediately went to the hospital where she learned that her daughter had succumbed to her injuries, while her husband and three remaining children were in a very serious condition, which resulted in her nervous breakdown. Upon the advice of her attorney, who told her that UK courts were awarding damages for psychological sufferings to people who saw their closed relatives in difficult conditions after the accident, Mrs. McLoughlin decided to sue the driver whose reckless driving caused the accident, along with other participants involved in this tragic case in different ways. In previous cases, the court awarded had awarded damages to people who were at the scene of an accident or who appeared there a few minutes after the accident, while in one case from 1967 the award was granted to an individual which was not in any close kinship to the victims. While drafting a claim, Mrs. McLoughlin's attorney quoted all these cases as precedents.

The doctrine of precedent obliges courts to follow previous court decisions in similar cases. The problem with the application of the doctrine is the determination of whether the cases are truly similar. Not a single case is identical to a previous one, but jurists agree that regardless of the differences, similar cases share essential elements. The trial judge who first acted in the McLoughlin case considered that the precedents quoted in the claim are essentially different than Mrs. McLoughlin's case. The trial judge said that in these precedents the award was granted for psychological suffering to individuals who were at the scene of the accident, while Mrs. McLoughlin suffered a shock in the hospital, about two hours after the accident. Since all courts follow the principle of common law stating that people who act negligent can only be held responsible for damages caused to another which could have been reasonably predicted, the trial judge was of the opinion that the difference between the cases was very significant, because a reasonable individual could have predicted psychological suffering of close relatives at the scene itself, but not the suffering of a mother who witnessed the consequences of an accident in the hospital. 
A complaint was filed against the decision of the Trial Court. The Court of Appeal confirmed the decision and rejected the appeal, but on the basis of completely different argumentation compared to the one stated by the Trial Court. The Court of Appeal stated that it was reasonable to predict that the mother would rush to the hospital upon hearing the news and that she would suffer a shock when she learned about the death of her daughter and see the difficult condition of the injured members of her family. The Court of Appeal did not consider that such a difference was essential compared to previous cases, so the appeal was rejected for political arguments, and added that upholding the appeal of Mrs. McLaughlin would produce significant undesirable consequences for the society as a whole. Such consequences would be reflected in a greater number of lawsuits because of psychological suffering which would overload the courts, while the expansion of the established rule on cases of suffered shock away from the scene of an accident would create an opportunity for various abuses and stating of false claims. All of this would significantly raise the price of auto liability insurance policies and probably prevent poorer members of the society to own or use their own vehicles.

Mrs. McLoughlin finally appealed to the House of Lords, which unanimously decided to abolish the decision and order a repeat trial before the Court of Appeal. Even though the decision was unanimous, lords disagreed regarding what they called the "true state of the law". 9 Some of them considered that political reasons may be determining in reply to the question of whether a certain accident was similar to some previous one and whether these reasons, in certain situations, justify the notion of the court to, for example, fail to extend the field of responsibility. But they nevertheless stated that political reasons were not sufficiently convincing in the given case, so they rejected the argument of the Court of Appeal stating that a danger loomed from an increased number of lawsuits, stressing that courts must differentiate true from false lawsuits. On the other side, two lords have voiced completely different arguments. As opposed to judges of the Court of Appeal and their lord colleagues, they have not agreed that justified lawsuits can be disputed at all for political reasons. "The precedents should be regarded as distinguishable, they said, only if the moral principles assumed in the earlier cases for some reasons did not apply to the plaintiff in the same way. And once it is conceded that the damage to a mother in the hospital hours after an accident is reasonably foreseeable to a careless driver, then no difference in moral principle can be found between two cases. Congestion in the courts or a rise in the price of automobile liability insurance, they said, however inconvenient these might be to the community as a whole, cannot justify refusing to enforce individual rights and duties that have been recognized and

9 R. Dworkin, Law's Empire, 27. 
enforced before". ${ }^{10}$ Simply said, they established that political arguments play a very important role in the lawmaking process, but not in the adjudication process, as two very different types of processes are in question, the purpose of which is also quite different.

The McLoughlin case is an example of theoretical disagreement about law. In the notions of members of the House of Lords, there was no consent on the role and importance of political reasons on one hand, and moral principles on the other. Regardless of the fact that in their decision lords came to the same conclusion, the question of how they understand the grounds of law remained open. Do all of these grounds include only legal acts and precedents? Why is disagreement so easily recognized in their interpretation concerning the principle of precedent? Do grounds of law also purport, aside from the above, political reasons or moral principles? In which way do political reasons and moral principles affect rights and obligations of the parties in dispute? Are they binding on the court? Dworkin thinks that all these questions troubling judges during adjudication in hard cases are not on the level of empirical disagreement about law, but that they represent theoretical disagreements on the grounds of law to which positivism as a plain-fact theory of law cannot provide proper answers. Studying hard cases shows that among judges, as state officials, there is no consent about what in their legal system actually represents grounds of law, so, accordingly, there can no consent among them about which legal provisions in particular cases are true, and which are false. In other words, disagreements on the question of law in particular cases (i.e. whether Mrs. McLoughlin has the right to damages for suffered mental anguish) stems directly from disagreement over grounds of law.

Dworkin's conclusion in regards to theoretical disagreement about law directly affects the main science of modern positivism, the science which represents from Hart onwards one of his basic methodological assumptions. This science is characterized by the notion that the law is of a conventional nature, and the notion that among state officials there is consent regarding facts which represents criteria for the identification of the law. These criteria are characterized in one final test of verification of validity, which Hart calls the rule of recognition and the obligation of which lies in the fact that it is accepted by state officials. The assumption that all other rules of the system draw their validity from the rule of recognition, while it still remains just an originary rule, leads Dworkin to the conclusion that modern legal positivism actually represents one plain-fact theory of law.

The reason for this claim Dworkin finds in the semantic nature of legal positivism. Legal positivism, like other important theories of law, is

10 Ibid., 28. 
according to Dworkin, semantic, because it tries to identify common criteria which are followed by jurists when they evaluate propositions of law. Jurists, just as any other participants in oral practice, follow certain common criteria when they use a certain word. If the word "law" is in question, then, according to semantic theories, jurists accept the same criteria in shaping, accepting and rejecting expressions of what the law is, like how other participants in oral practice accept common criteria when they use a certain word, such as "house" or "airplane". Simply said, if there were no general acceptance of criteria, one could hardly discuss with any proper understanding among participants in oral practice. On the basis of this observation, Dworkin stresses that the main task of the philosophy of law would be to establish common criteria through the analysis of the word "law". Of course, among law philosophers themselves there could be disagreements concerning the common criteria, but, on the other hand, all of them follow the same assumption - that participants in the law practice share a certain set of criteria when they use the expression "law".

Methodologically speaking, the structure of modern legal positivism as a dominant theory is rather simple - the accuracy of a certain proposition of the law depends on the grounds of the law, which are by their very nature historical facts, and which are accepted as common criteria for the identification of the law. So, a certain proposition of the law in an Anglo-Saxon legal system would be true if adopted on the basis of the law or precedent, because laws and precedents are considered common criteria for the identification of the law. In short terms, positivism starts from the assumption that there is a general consensus among jurists on the grounds of law. This fact, which actually supports the notion of legal positivism on the conceptual detachment of law and morality, according to Dworkin represents the main reason why positivism is not capable of performing its main task, and why it is not capable of properly describing legal practice. So, for example, since the adoption of the Fourteenth amendment until the Brown case nothing among the historical facts changed. However, one thing did changed, and that was the moral comprehension of the fact that segregation does not represent respect for equality, but is rather an expression of racial inequality. That is the true reason why the Supreme Court changed its opinion and proclaimed segregation unconstitutional.

\section{ARGUMENTS FOR THE DEFENSE OF POSITIVISM}

Within his methodological criticism of legal positivism Dworkin has also analyzed arguments which could support the positivist thesis on law as a plain fact and the claim that the only sensible discussion about 
law is necessarily empirical, and not theoretical. The first argument which could explain the positivists' apparent theoretical disagreement about law, lies in the notion that in hard cases dispute does not concern what the law actually is, but what the law should actually be. ${ }^{11}$ This is why, according to the positivists" understanding of the law as a plain fact, judges were prone to repairing the existing law in hard cases. From the positivists point of view, the fact that the rhetoric of judges in most hard cases does not focus on repairing, but rather on revealing and applying the existing law, is justificatied in modern legal systems in which there is a wider or stricter division of legal, executive and judicial authorities. In these systems where, in general, the lawmaker adopts, and courts uphold and apply the laws, judges are not prone to admitting that by performing their function, in fact, they correct the existing law. Exactly because of this, their arguments frequently show that the case involves a theoretical disagreement about the law, and not what this is actually all about - the practice of judicial discretion and improvement of the existing law.

Dworkin does not share this viewpoint. Hence, the Court of Appeal judges in the McLoughlin case have, it seems, thought that there was no right arising from mental anguish suffered at of the place of accident, since previous verdicts only related to the places of accidents, so they thought that their task was to, taking all circumstances into consideration, correct this and improve the law in the best possible way. However, the House of Lords did not concur with this, especially not the lords who separated their opinion, as they considered that they were obliged by moral principles established by previous precedents. Members of the House of Lords were unanimous with judges of the Court of Appeal and, like them, they were aware of the importance of the political argument that awarding of damages in a given case could harm the community as a whole, but they were not unanimous concerning the power and character of precedents as the source of law. According to Dworkin, "though the disagreement was subtle it was nevertheless a disagreement about what the law was, not about what should be done in the absence of law. ${ }^{12}$

The other argument which could support the positivists' understanding of the law as a plain fact is more sophisticated than the previous one. Namely, this argument stresses that there are differences between standard or common cases of the use of the expression "law" and those cases which could be considered as borderline. For example, categorical legal rules like the speed limit on public roads or the tax rates do not leave any space for disagreement- neither regarding their legality nor in the sense of their content and meaning. However, the rules on the use of expressions are not exact and borderline cases may occur. In these cases,

11 R. Dworkin, ibid., 46, S. Shapiro, ibid., 33.

12 R. Dworkin, ibid., 39. 
jurists may use the expression "law" differently, as then only some, and not all the grounds can be identified which are stipulated by the rule of recognition. ${ }^{13}$ This is the way in which their disagreement is explained in hard cases, as the use of the expression "law" does not differ from the use of some other expression which is considered undisputed, like the expression "house". ${ }^{14}$ Simply said, people mainly agree about the standard meaning of a certain expression, but since not everyone follows exactly the same rules, and since the rules are not completely exact, it can be disputable whether, for example, the White House could be considered a house. On the basis of this argument it turns out that jurists and judges especially, sometimes do not agree on the status of law, but these disagreements are of a verbal and not of a theoretical nature.

According to this type of argumentation, it is possible to correctly understand the legal phenomenon if the expression "law" is used to describe only what represents the core of the term law, and if it is used in a way which includes only those legal provisions which are true according to the central rule for the use of expression "law", like provisions on the speed limit on highways. ${ }^{15}$ Hard cases should be considered a question of correcting the existing law, regardless of whether the judges in such cases truly understood that they were doing just that. In order words, if some case cannot be solved with the application of a generally accepted rule on the grounds of law, then the action of judges in such hard cases becomes a question of how should judges actually develop and improve the law.

Dworkin rightfully wonders how cases like the McLoughlin case can ever be called a borderline case. First of all, if a parallel is drawn between these cases concerning the problematic use of the expression "law" and other, legal borderline cases common in the language practice, it is clear that with the latter there are no reasons for discussing them excessively. Simply, people generally don't spend much time discussing whether the White House could be considered a house or whether an amphibian vehicle is a vehicle or vessel. As opposed to these examples from the language practice, the defense of positivism with borderline cases omits that hard judicial cases are those which cause the most legal arguments, which are broadly discussed and which assume central positions in legal reviews and textbooks. Also, it is impossible to neglect numerous other very important questions which are opened by these cases, like political questions regarding division of state power, questions of basic legal values such as equality, freedom, etc. It is not possible, or even desirable, to consider these cases as borderline, as big issues obviously cannot be studied in this way on the basis of a language analysis of the use of expression "law".
13 Ibid.
14 Ibid., 40.
15 Ibid. 
Most importantly, Dworkin claims that this sophisticated defense of the positivists ' understanding of the law as a plain fact with the assistance of borderline cases neglects the differences between two types of disagreements. The first type of disagreement relates to borderline cases, while the second type of disagreements pertains to pivotal cases, and on disagreements concerning the truthfulness of tests for the use of expressions or terms. In the first case, it is possible to imagine a dispute on whether a palace or court could be considered a house, as according to certain characteristics the palace or court are identical to the term house as they all serve for dwelling, but according to some they are not, as they describe especially large and luxurious facilities, to which the common use of the term house certainly does not apply to. In the second case there is no consent concerning the question of the legal meaning of a certain expression, i.e. if a disagreement would be conceived regarding the question of whether a house represents a facility for the dwelling of people at all.

In order to explain this in more detail, Dworkin used an imaginary discussion between two art critics on whether photography could be considered as art. Roughly viewed, two types of discussions are possible in this case. In the first discussion, there can be consent between the two critics that photography is in some elements similar, or not similar with some other phenomena like sculpting or painting, which represent art in the true sense of the word. They can agree that photography in the best case represents a borderline form of art, and on the basis of this they would also agree that the decision of whether photography should be considered art is arbitrary in the final instance and that the adoption of such a decision is mainly motivated by some other reason (i.e. for the purpose of easier presentation in some modern art textbook). Hence, there is no reason for them to discuss whether photography represents a "true" art. On the other hand, it is possible to imagine a completely different discussion in which one of the critics claims that photography represents an example of the art form, while the other one supports a completely different opinion and claims that photography cannot be classified as art, since photographic techniques are essentially foreign to the goals of art. In the case of this second discussion, one can no longer talk about the question of where to draw a border line, as the critics' comprehension of art is so different that they observe even standard forms of art, like sculpting and painting, to be standard for completely different reasons. ${ }^{16}$

On the basis of this parallel, Dworkin concludes that a sophisticated defense of positivism on the basis of borderline cases completely exceeds the essence of the problem, as it fails to recognize these two differences. Figuratively said, judges in the so-called hard cases are not in the position of two art critics which argue where the border line should be

16 Ibid., 41-42. 
drawn and whether photography should be included in the modern art textbook or not, but are in the second position of two critics who differently understand the art itself. Because of missing so many different types of disagreements, such defense of positivism leads in the wrong direction and blurs the fact that among many judges who tried hard cases there was, actually, a profound disagreement on the law and precedent.

\section{ONE POSITIVIST REPLY}

Using the analysis of hard cases Dworkin successfully proved the existence of a theoretical disagreement about law. The cases he analyzed showed that neither an inclusive nor exclusive line of positivists' defense is appropriate for explaining the obvious theoretical disagreement among judges in such cases. Regardless of not so insignificant differences, both positivistic routes share the same methodological ground which in short says the grounds of law are determined by a consensus among state officials. Understandably, the question remains how positivists "account for disagreements about the legal bindingness of certain facts whose bindingness, by hypothesis, requires the existence of agreement on their bindingness?" 17 On the other hand, it is amazing how, regardless of so much ink spilled in the so-called Hart-Dworkin debate, so little attention was paid to this exceptionally convincing argument of Dworkin's.

There are several possible explanations of positivistic indolence towards Dworkin's argument on theoretical disagreements about law. One of the reasons could be grounded in Dworkin's insistence on presenting positivism as a semantic theory. With this argument Dworkin tried to prove how positivism, from its methodological foundations, is not capable of detecting a true type of disagreement, but only empirical disagreements on the existence or non-existence of certain historical facts. $\mathrm{He}$ baldly claimed that the so-called semantic sting simply paralyzes legal positivism and leaves him on the surface of the problem. Positivists have successfully refuted the semantic sting, but have overlooked the fact that regardless of it, the argument on theoretical disagreement remains. The validity of the argumentation on theoretical disagreement is not connected to, or at least has no direct connections with, the semantic sting with which Dworkin tries to prove how positivism cannot count on such a form of disagreement. And so, several years ago, the debate in jurisprudence on the topic of semantic sting ended, with positivists making a convincing defense against Dworkin's attacks, but also against the arguments of his followers, ${ }^{18}$ while the debate on theoretical disagreement about law still hasn't been opened in the right way.

17 S. Shapiro, ibid., 38.

18 See Veronica Rodriguez-Blanco, "A Defence of Hart's Semantics as Nonambitious Conceptual Analysis", Legal Theory, 2003/9, 100. Nicos Stavropoulos, "Hart's Se- 
The second possible explanation may lay in the assumption that positivists haven't noticed how the argument on theoretical disagreement about law is, by its nature, significantly different than semantic sting, but also in comparison to criticism about the explanatory strength of legal positivism. To this latter criticism, positivists replied by arguing that the grounds of law are determined by convention among officials. This type of previously stated defense, which was used against Dworkin's arguments about the explanatory weakness of legal positivism, cannot be used against the argument on theoretical disagreement as well, which in essence does not differ from the previous one, since this argument attacked exactly this positivistic defense and the main methodological science of modern positivism on the conventional nature of law.

In the end, as a possible explanation of the insensitivity and disinterested positivists show towards Dworkin's arguments on theoretical disagreement about law, a notion can of, above all, exclusive positivists can be used, which is also quoted by Dworkin. It states that theoretical disagreement does not exist, that this is only a mirage or deception. Since the grounds of law are fixed by convention, each theoretical disagreement is excluded, which is also claimed by Dworkin, while cases which only resemble theoretical disagreement actually represent examples of repair arguments, which are opposed by Dworkin.

Scott Shapiro is one of few reputable legal positivists who addressed Dworkin's argument on theoretical disagreements about law. ${ }^{19}$ As Shapiro notes, judges are not the only ones involved in theoretical disagreement, as they are also accompanied by legal theorists who study legal practice. And while judges, as members of the separate segment of authorities, frequently conceal that such theoretical disagreement exists among them at all for political reasons, ${ }^{20}$ legal theorists, sometimes unconsciously, broadly discuss it. The true example of such a discussion is a discussion about which is the best or the most suitable way of interpretinglegal rules, in which theorists advocate different conceptions such as textualism, originalism, purposivism, doctrinalism, etc. ${ }^{21}$ All these conceptions, which propose or argue for a certain interpretative methodology of legal provisions, represent nothing else but theoretical disagreement about the law, simply because a replay to the question what is law in some particular case, depends on a way of interpreting propositions of

mantics", y Hart's Postscripts, Jules Coleman, (ed.), Oxford University Press, Oxford/ New York, 2001, 62.

19 Ibid., 40-52.

20 If we were to assume the contrary, that judges openly acknowledge theoretical disagreements among them, established legal principle iura novit curia would be brought into question.

21 Scott J. Shapiro, "What is the Rule of Recognition (and does it exist)?", Public Law \& Legal Theory Research Paper Series, Research Paper No. 181, 2009, 15-16. 
law. "Positivists, therefore, appear to be in an awkward position. If they wish to deny the existence of theoretical legal disagreements, they are forced to say that legal scholars are so confused about the practice they study that they routinely engage in incoherent argumentation". ${ }^{22}$ This, in turn, definitely represents an unpleasant conclusion for positivists, but as Shapiro claims, establishing his basic thesis against Dworkin's argument, this does not mean that positivists should avoid this argument, but rather acknowledge it while not abandoning the positivists' methodological foundation.

The first step toward the inclusion of the theoretical disagreement problem into a positivistic framework, according to Shapiro, is rejecting the notion of the existence of a convention among judges on the proper interpretation of the law, because a suitable way of interpreting the law can also be fixed in a different way. Even though judges in their deliberations most frequently fail to raise the issues of theoretical disagreement, they certainly exist, which is demonstrated by the case of "Edwards vs. Canada", where the court, which is completely unusual, in its deliberation rejected originalism as a suitable method of interpretation of the Constitution. The second step involves positivists agreeing with Dworkin's notion that when a theoretical disagreement appears in the law, establishing a proper way of interpretation always involves attributing certain purpose to the legal practice. On the contrary, if a disagreement on the proper way of legal interpretation would be separated from the purpose of legal practice, then it would be difficult to understand why the disagreement exists at all. Finally, positivists should agree with Dworkin that in such cases the main role of the proper interpretation of particular propositions of law is in interpreting such propositions in accordance with the goals of the legal system. This is also the last point over which positivists need to agree with Dworkin's notions, and after that they should distance themselves from the basic postulates of his theory. Even though positivists need to attribute some purpose to a certain legal system, they should not do so in Dworkin's way, but should, using empirical methods, seek it in social facts. The correct way of interpreting the law would then be established with a reply to the question of which of the existing ways is the most compliant with the recognized goals and values of a particular legal system. Shapiro claims that positivism will thus significantly reduce the power of Dworkin's criticism, adding that "by claiming that interpretive methodology is a function of empirically derivable objectives, the positivist will have grounded the law in social fact". ${ }^{23}$ Moreover, positivists shall, going down that road, establish social foundations of the law to some extent in a different manner than before, by abandoning the notion that all correct ways of interpreting the law are determined by special

22 S. Shapiro, "Hart-Dworkin debate", 41.

23 Ibid., 43. 
conventions among judges and thus enable for positivism to accept the theoretical disagreement about law which was undoubtedly proven by Dworkin. In this case, the theoretical disagreement would only appear as a consequence of the discussion about goals of the legal system and the ways of interpretation which are most compliant with this purpose.

\section{CONCLUSION}

It seems that the above-presented defense against Dworkin's argument on theoretical disagreement actually shows all of its strength. Freely speaking, Shapiro, in his intention to blunt the edge of Dworkin's criticism, actually cut himself in the process. His defense for the purpose of recognition of the obvious truth that theoretical disagreement about law truly exists, involves certain elements which are very close to Dworkin's theory, while in those parts of his argumentation which redefine methodological grounds of positivism, solutions are offered which positivism is not capable of offering. One does not need to go further from the question which, for so long, bothers even the greatest legal philosophers - by using which empirical method is it possible to attribute purpose or purposes to the legal practice, and how to find it in social facts?! If positivism develops such a method while not abandoning its methodological foundations, then Shapiro's argument would have the necessary strength, even though the acknowledgment itself that theoretical disagreement exists and that modern positivists should not act like ostriches, represents a step in the right direction. 